\title{
UNIKANIE I UCHYLANIE SIĘ OD OPODATKOWANIA JAKO SPOSOBY ZARZĄDZANIA PODATKAMI KONSUMENTA - O ZAGROŻENIACH I PRZECIWDZIAŁANIU
}

Damian Abramczyk Wydział Ekonomiczny, Uniwersytet Marii Curie-Skłodowskiej w Lublinie

\section{Streszczenie}

Podstawowym celem konsumenta jest nieustanne zaspokajanie swoich potrzeb, co realizuje się przez wydatkowanie wcześniej zgromadzonych dochodów. Ten dąży do ciągłego polepszania swojej sytuacji materialnej. Wypracowane dochody stanowią główny sposób utrzymania jego oraz jego najbliższych. Te, w swojej definicji spełniają jednak wiele innych, równie istotnych funkcji - ich odprowadzona część zasila bowiem budżet Skarbu Państwa, który, na drodze redystrybucji, zostaje pożytkowany na potrzeby zbiorowe społeczeństwa. Bardzo często spotyka się to z dezaprobatą i ogólną niechęcią opodatkowanych. W poniższym artykule zostaną przedstawione najważniejsze funkcje systemu podatkowego, w oparciu o system obowiązujący na terenie Rzeczpospolitej Polskiej. Zawiera on także reakcje podatników na obecną sytuację prawno-ekonomiczną oraz ukaże najbardziej podstawowe sposoby unikania oraz uchylania się od opodatkowania.

Słowa kluczowe: podatek, system podatkowy, unikanie od opodatkowania, uchylanie się od opodatkowania, funkcje podatków, cele podatków, cechy stałe podatku.

JEL Class: H26. 


\section{WPROWADZENIE}

Naturalnym pragnieniem człowieka jest posiadanie w swoim dorobku jak największej ilości dóbr, zarówno w postaci materialnej jak i finansowej. Człowiek za poczucie dobrobytu i stabilności jest w stanie pracować bardzo ciężko, nawet przez długie lata. Jest on jednak zaledwie elementem finansów publicznych państwa. To ono wymaga od niego składania obowiązkowych danin na rzecz społeczeństwa. Jednak jest przede wszystkim konsumentem - ostatecznym ogniwem i odbiorcą procesu produkcji. Tworzy własne gospodarstwo domowe - rodzinę, którą ma w obowiązku utrzymać. Nie bez powodu „dąży do tego, by zawsze mieć więcej niż mniej”. Wobec tego, naturalnym stało się pojawienie zjawiska ucieczki bądź uchylania się od obowiązków podatkowych. Powszechność tego zachowania wynika $\mathrm{z}$ naturalnej niechęci do płacenia podatków. Każdy podmiot, zarówno małe gospodarstwa domowe, jak i duże przedsiębiorstwa dążą do minimalizacji zobowiązań. Jakie są więc metody i środki, legalne bądź nie, które pozwolą podatnikom na optymalizację zobowiązań? Celem niniejszej pracy jest wskazanie na różnice, przyczyny i skutki pojawiania się tych zjawisk w społeczeństwie oraz wskazanie na zachowania mające na celu usprawnienie procesu optymalizacji podatkowej oraz uszczelnienie systemu podatkowego w sytuacji uchylania się od opodatkowania przez podmioty znajdujące się na terytorium Rzeczpospolitej Polskiej. Do ich identyfikacji posłuży dostępna literatura przedmiotu, aktualne normy prawne, a także branżowe artykuły publicystyczne.

\section{WPROWADZENIE DO TEORII PODATKU. CHARAKTERYSTYKA SYSTEMU ZOBOWIAZZAŃ PODATKOWYCH NA TERENIE RZECZPOSPOLITEJ POLSKIEJ}

Podstawowym zadaniem systemu podatkowego jest zapewnienie płynności finansowej w sferze finansów publicznych państwa. Wpływy z tego tytułu stanowią bowiem największy udział $\mathrm{w}$ dochodzie publicznym. Aby pokrótce przedstawić polski system podatkowy należy wprowadzić pewne definicje, oparte o literaturę prawa. Mianem obowiązku podatkowego nazywamy pewną powinność w stosunku do Skarbu Państwa $\mathrm{z}$ tytułu wykonania czynności bądź nabycia dobra, określonego przez Ustawodawcę w Ordynacji Podatkowej. Podatkiem nazywamy więc pewne świadczenie finansowe, przekazywane bezpośrednio na ręce budżetu Skarbu Państwa, bądź budżetu jednostki samorządu terytorialnego. Skonkretyzowany o termin, wysokość i miejsce uiszczenia płatności obowiązek podatkowy przekształca się w zobowiązanie podatkowe, do zapłacenia którego zobligowany jest podatnik formalny - tj. określony w przepisach podatkowych. Cechy stałe podatku, wcześniej wspomniane i rozbudowane o poszczególne definicje przedstawia rysunek 1. 


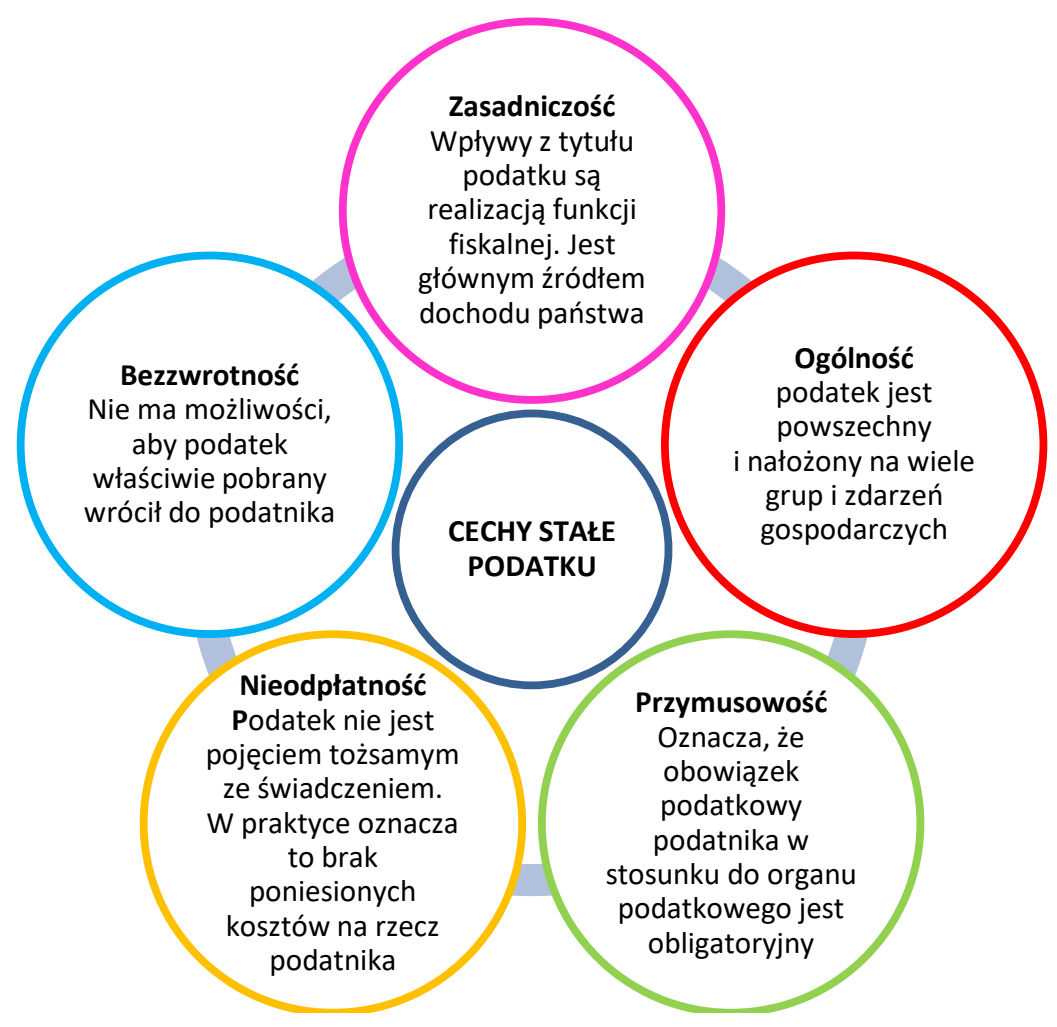

Rysunek 1 . Cechy stałe podatku

Źródło: opracowanie własne na podstawie: Smoleń [2017: 8].

Podatek stanowi więc narzędzie regulacji i kreowania budżetu państwa bądź jednostek samorządu terytorialnego. Podmiotem zobligowanym do jego uiszczenia litera prawa definiuje jako podatnika, mającego status osoby fizycznej, prawnej bądź tak zwanej ułomnej osoby prawnej [Ustawa z dnia 29 sierpnia 1997 r. Ordynacja podatkowa [Dz.U. 2018, poz. 800], Ustawa z dnia 26 lipca 1991 r. o podatku dochodowym od osób fizycznych [Dz.U. 2018, poz. 1509]. Podatnik jest odpowiedzialny za odprowadzenie podatku, wcześniej naliczonego przez płatnika. Praktyka pokazuje jednak rozłam pomiędzy podatnikiem i płatnikiem formalnym oraz rzeczywistym. Mianem formalnego określa się podmiot faktycznie objęty obowiązkiem podatkowym zgodnie z przepisami prawa podatkowego. $Z$ kolei podatnik rzeczywisty, choć nie zobowiązany do opłaty świadczenia podatkowego, ponosi i odczuwa ciężar ekonomiczny tego zdarzenia. Mówiąc inaczej - podatnik rzeczywisty traci zarobione wcześniej pieniądze na 
skutek przerzucenia odpowiedzialności ekonomiczno-podatkowej na rzecz podatnika formalnego.

Podatek, jako narzędzie ekonomiczne służy także realizacji pewnych celów w ramach gospodarki narodowej. Ze względu na zastosowanie, specjaliści z zakresu ekonomii dokonali ich podziałów na fiskalne i niefiskalne [Cieślukowski $\mathrm{i}$ in. 2012]. Wpływ tej pierwszej jest kluczowy w systemie zarządzania podatkami państwowymi. Celem fiskalnym jest bowiem pozyskanie środków do budżetu państwa, które następnie są redystrybuowane pomiędzy poszczególne segmenty życia obywateli. Wpływy podatkowe mają bowiem za zadanie skompensować wszelkie wydatki administracji państwowej na realizacje zadań sektora publicznego. Pozostałe, pozafiskalne cele, zostały przedstawione na rysunku 2.

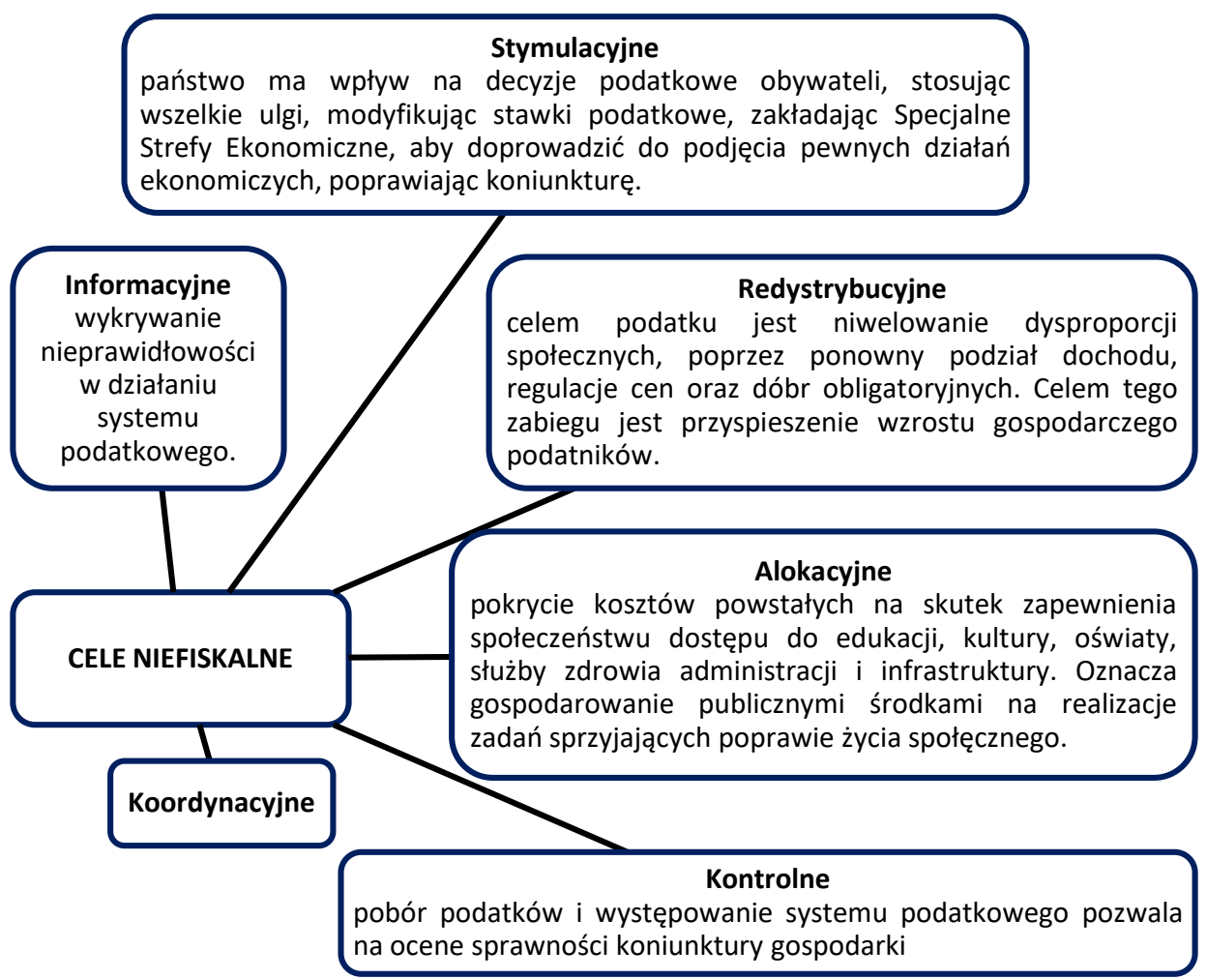

Rysunek 2. Cele niefiskalne podatków

Źródło: opracowanie własne na podstawie: Dzwonkowski (red.) [2012: 18-19]. 
Nasuwa się więc wniosek, że system podatkowy ma charakter bardzo skomplikowany oraz składa się z wielu czynników i mechanizmów nawzajem się przenikających. Świadczy o tym chociażby redystrybucja pieniądza pozyskanego na skutek poboru podatku przez organ podatkowy i jego alokacja pomiędzy poszczególne segmenty społeczeństwa. Bez wątpienia zajmują one szczególne miejsce w sferze życia obywateli, ponieważ towarzyszą im praktycznie w każdej dziedzinie życia.

$\mathrm{Na}$ obowiązujący polski system podatkowy składa się blisko 20 różnych podatków, których zadaniem jest zasilanie budżetu. Ten, jak już wcześniej wspomniano, dzieli się na budżet państwowy i samorządowy. Zdecydowanie najpowszechniejszym podziałem podatku jest kryterium ze względu na sposób egzekwowania podatku - wówczas mówimy o podatkach pośrednich i bezpośrednich. W tych pierwszych ustawodawca dopuścił możliwość rozszczepienia podatnika formalnego i rzeczywistego. Przykładami takich podatków są Podatek od Towarów i Usług, bliżej znany jako podatek VAT, podatek od gier czy podatek akcyzowy na niektóre wyroby, takie jak alkohol, paliwo czy papierosy. Podatkami bezpośrednimi nazywamy te podatki, w których wcześniej wspominany rozłam jest niemożliwy, niezagwarantowany przez ustawodawcę. Wówczas mowa o podatkach dochodowych od osób fizycznych (PIT) oraz prawnych (CIT), a także podatki o szczeblu samorządowym - rolny, leśny, od nieruchomości, od środków transportu, spadków i darowizn, czynności cywilnoprawnych, czy uproszczona forma podatku dochodowego - karta podatkowa.

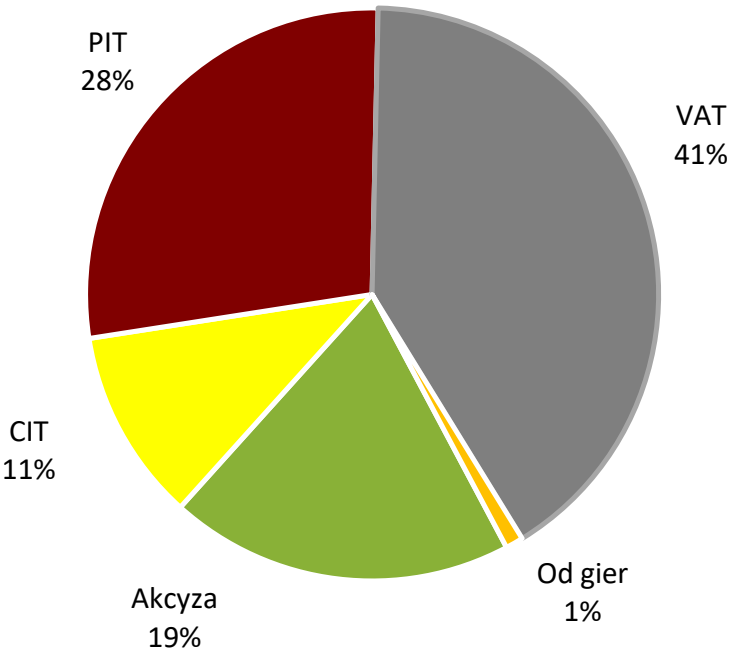

Rysunek 3. Udział poszczególnych podatków w dochodzie w roku 2017

Żródło: opracowanie własne na podstawie danych z Ministerstwa Finansów. 
W polskim systemie podatkowym, pod względem wydajności oraz ilości wypływów do budżetu dominują podatki pośrednie. Podatek od towarów i usług jest naliczany na każdym sprzedanym dobru bądź usłudze na każdym etapie od pozyskania materiału do ostatecznej konsumpcji w gospodarstwie domowym. Z kolei podatek akcyzowy, nakładany na wąski asortyment dóbr staje się łatwym z perspektywy budżetu państwa sposobem na akumulację środków. Podatek ten obejmuje więc wszystkie używki, ograniczając ich spożycie oraz pewną grupę produktów, których wartość sprzedaży znacząco przewyższa koszty produkcji na przykład wyroby energetyczne [Ustawa z 6 grudnia 2008 o podatku akcyzowym [Dz.U. 2018, poz. 1114] obowiązująca od 1 marca 2009].

Jak wcześniej zauważono podatki swoim zasięgiem obejmują nie tylko szczebel państwowy, ale także jednostki samorządu terytorialnego. Te także mają swoje udziały w podatku dochodowym, o czym świadczą dane z tabeli 1 .

Tabela 1. Udział poszczególnych jednostek samorządu terytorialnego w dochodach $\mathrm{z}$ tytułu podatku dochodowego

\begin{tabular}{|l|c|c|c|}
\hline & Województwa & Powiaty & Gminy \\
\hline $\begin{array}{l}\text { Udział podatku dochodowego od osób } \\
\text { prawnych }\end{array}$ & $14,75 \%$ & $1,4 \%$ & $6,71 \%$ \\
\hline $\begin{array}{l}\text { Udział podatku dochodowego od osób } \\
\text { fizycznych }\end{array}$ & $1,6 \%$ & $10,25 \%$ & $37,89 \%$ \\
\hline
\end{tabular}

Źródło: opracowanie własne na podstawie danych z Ministerstwa Finansów.

Daje to do zrozumienia, że podatnicy odprowadzający podatek dochodowy zasilają w takim samym stopniu zarówno budżet państwa, jak i wszystkich jednostek samorządowych - gmin, powiatów, województw, tym samym wspierając rozwój lokalnej społeczności oraz innowacji na terenie zamieszkiwanego regionu.

\section{ZACHOWANIA KONSUMENTÓW NA ZMIANĘ SYSTEMU PODATKOWEGO - ZJAWISKA UNIKANIA I UCHYLANIA SIĘ OD OPODATKOWANIA, ICH ISTOTA I ZNACZENIE}

Podstawowym celem podatków jest pozyskanie pieniędzy ze środków zgromadzonych przez podatnika na skutek wykonanej pracy bądź posiadanego majątku. Oczywistym jest więc niechęć z ich strony do przekazywania części zarobionej przez siebie sumy na rzecz Skarbu Państwa. Nieustannie zmieniająca się koniunktura wymusza na aparacie rządowym kontrolę nad panującym systemem podatkowym. W momencie jej osłabienia niezbędnym jest wykorzysta- 
nie mechanizmów, które przyspieszą ją w jak najkrótszym czasie. Takie zmiany systemu gospodarczego zmuszają do zmiany stawek opodatkowania niektórych podatków, bądź do wprowadzenia nowych, unikalnych zobowiązań podatkowych. Takie działania spotykają się z różną reakcją podatników. W praktyce osoba obciążona takim zobowiązaniem ma kilka możliwości reakcji. Zawsze jednak wywołuje ona niechęć do uiszczenia wymaganego zobowiązania. Opodatkowany może pogodzić się z faktem zaistnienia obowiązku podatkowego i zapłacić jego pełną sumę, może zrezygnować z prowadzonej przez siebie działalności bądź całkowicie zaniechać czynności objętej obowiązkiem podatkowym, może także przerzucić ciężar opodatkowania w przód na konsumenta bądź w tył na dostawcę towaru lub usługi. Ostatecznie może także uniknąć lub całkowicie uchylić się od opodatkowania. Na tych dwóch ostatnich warto skupić się najuważniej.

Negatywne reakcje na opodatkowanie stały się na tyle problemem palącym, że literatura zdefiniowała prawo narastającego oporu wobec systemu podatkowego. Zarządzanie podatkami ma więc też istotny wpływ, nie tylko w kontekście pozyskiwania środków do budżetu państwa, lecz także z perspektywy gospodarstw domowych. Warto zaznaczyć, że w procesie kształtowania budżetu system podatkowy odgrywa bardzo istotną rolę. Zobowiązania podatników pełnią niejako funkcję stymulacyjną gospodarki [Kowalewska (red.) i Musiał 2016: 99-100], kreując nowe zachowania domowników. Obowiązujące normy prawne często są dla nich zawiłe, co również w efekcie prowadzi do negatywnych reakcji na opodatkowanie. W efekcie budżet dysponowany przez podatników bardzo często cechuje nieefektywność. Wzrost świadomości podatkowej w obrębie gospodarstw domowych może zmaksymalizować potencjalne korzyści podatkowe gospodarstw. Wykluczając asymetrię informacji możliwe jest także obustronne odniesienie korzyści $\mathrm{w}$ postaci niskich, zoptymalizowanych podatków oraz wyższe wpływy do budżetu państwa, bowiem ze względu na legalność działań poinformowani podatnicy będą korzystniej reagować na opodatkowanie.

Bezpośrednią przyczyną występowania zjawisk unikania bądź uchylania się od opodatkowania jest tak zwany „efekt Laffer'a”, z którego wynika, że wysokość dochodów z tytułu zobowiązań podatkowych rośnie tylko do pewnej wysokości podatku [www3, dostęp: 13.03.2019]. Po przekroczeniu pewnego ekstremum wpływy te zaczynają stopniowo opadać.

Definicja unikania obowiązków podatkowych określa zarówno legalne jak i nielegalne działania dążące do minimalizowania zobowiązań podatkowych [www6, dostęp: 13.03.2019]. Są to więc wszelkiego rodzaju sposoby optymalizacji podatkowej, a także sposoby ucieczki od obowiązku. Literatura wskazuje, że wytyczenie granicy legalności tych działań jest bardzo trudne, bądź też niemożliwe w realizacji. Tezę tę popiera złożoność tego zjawiska. Mianem tym definiuje się więc wszelkie dopuszczalne przez prawo działania dążące do mi- 
nimalizacji obciążeń podatkowych. Ważnym jest zachowanie należytej ostrożności w ocenie występowania tego zjawiska. Stoi ono bowiem w sprzeczności z zasadą ogólności opodatkowania, na mocy której wobec każdego podatnika stosuje się takie same zasady i sposoby poboru zobowiązania podatkowego.

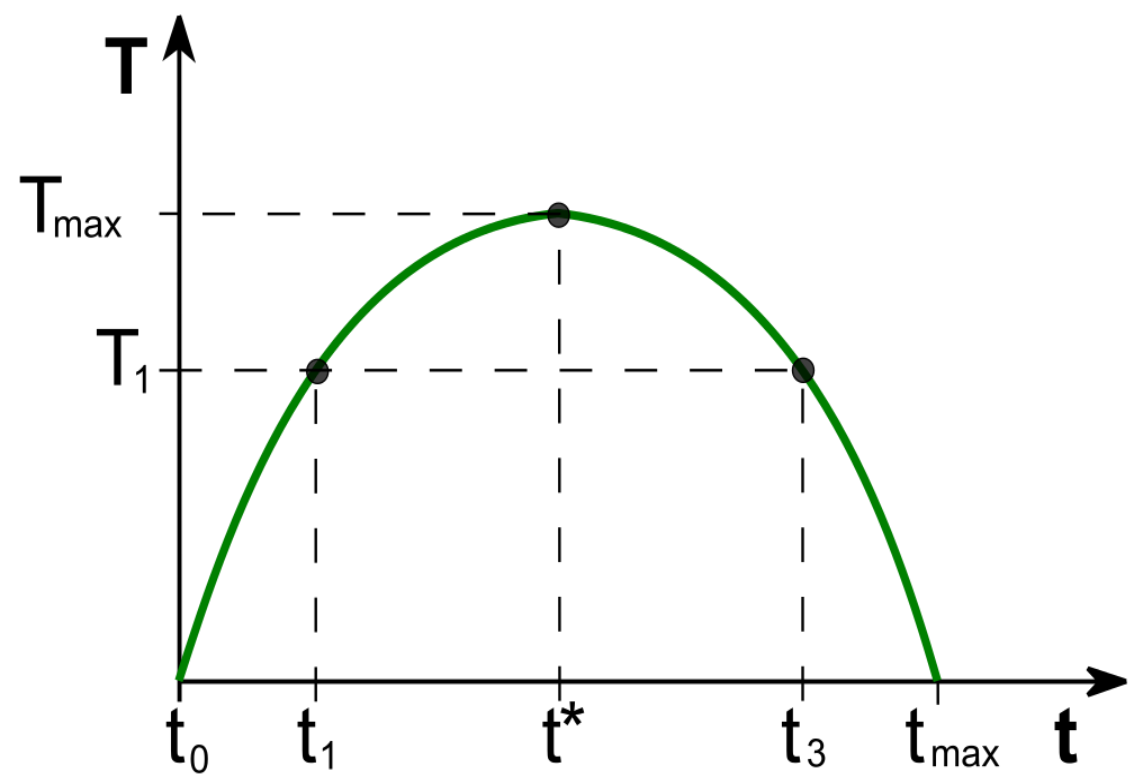

Rysunek 4. Krzywa Laffer'a

Źródło: www5 [dostęp: 10.03.2019].

W praktyce podatnik może zoptymalizować ciążące na nim zobowiązania podatkowe. Stanowią one przejawy jego zdolności ekonomicznych i skłonności do zarządzania podatkami. Osobie opodatkowanej przysługuje wybór formy, w jakiej będzie się rozliczał, może także stosować wszelkie ulgi, określone przez Ustawodawcę w przepisach. Minimalizacja zobowiązań, która wykorzystuje zwolnienia bądź wcześniej wspomniane ulgi podatkowe nazywana jest metodą normalną optymalizacji podatkowej. Okazuje się, że niektóre działania w sferze optymalizacji podatkowej, choć formalnie legalne, są sprzeczne w kontekście moralnym. Podatnicy zorientowani w prawie podatkowym są w stanie dopatrzeć się wielu luk prawnych, które w efekcie doprowadzają do minimalizacji bądź całkowitego zaniku obowiązku podatkowego. Zachowania te są niegodziwe i zdecydowanie zasługują na potępienie przez opinie publiczną. 
Kolejną formą ucieczki od obowiązku podatkowego jest uchylanie się od opodatkowania. Literatura przedmiotu wykazuje je jako działania całkowicie sprzeczne $\mathrm{z}$ prawem i definiuje jako działania mające na celu dokonania oszustwa podatkowego w sposób całkowicie świadomy i wolny. Mowa więc o uchylaniu się od obowiązku podatkowego w sytuacjach, gdy podatnik świadomie wstrzymuje się od poinformowania organu skarbowego o zaistnieniu zdarzeń objętych obowiązkiem podatkowym. O uchylaniu się od opodatkowania mówi się także w sytuacji oszustw podatkowych, bądź wykorzystywaniu luk prawnych w celu pozyskania korzyści majątkowej w postaci zwróconego nienależycie podatku. Skutkiem działań podmiotów uchylających się od opodatkowania jest przede wszystkim utrata płynności sektora finansów publicznych państwa oraz występowanie tak zwanej szarej strefy. Termin ten jest powszechnie znany opinii publicznej. Definiuje się go jako prowadzenie działalności poza kontrolą organów państwowych [Fundowicz 2016: 6]. Na budowę szarej strefy składają się więc 3 fundamentalne czynniki - działalności nieformalne, nierejestrowane, działalności ukryte, częściowo legalne, lecz moralnie zakazane oraz nielegalne, które są objęte karą grzywny bądź pozbawienia wolności. Innym skutkiem występowania zjawiska uchylania się od opodatkowania jest rozszerzanie się tak zwanej „luki podatkowej”. Polska na tle innych krajów Unii Europejskiej plasuje się na jednym $\mathrm{z}$ ostatnich miejsc. Luka wynikająca $\mathrm{z}$ uchylania się od dokonywania uchylania się od płacenia podatku od Towarów i Usług wynosi około 24 punktów procentowych. Oznacza to że co czwarta transakcja VAT zawierana na terenie Rzeczpospolitej stanowi przejaw malwersacji podatkowych.

Spośród przyczyn powstania zjawiska uchylania się od opodatkowania można wyszczególnić przyczyny o charakterze społecznym, ekonomicznym oraz demograficznym. Podatnicy za wszelką cenę dążą do ograniczenia wydatków podatkowych. Bardzo często ma to podłoże behawioralne, kompletnie zapominając o kwestiach etycznych. Konsument dąży do maksymalizacji efektu przy minimalizacji wszelkich kosztów. W praktyce posuwa się do nielegalnych form i działań, które powodują hamowanie procesów gospodarczych. Przestępcy podatkowi nieustannie analizują przepisy prawa, doszukując się nowych przepisów, które w sposób łatwy i bezpieczny mogą ominąć, tym samym pozyskując środki. Robią to w sposób wyszukany oraz inteligentny. Do dokonywania tego typu przewinień zachęca niskie ryzyko i towarzyszące mu ogromne zyski z tego tytułu. Do najczęstszych działań oszustów podatkowych zalicza się tak zwane „transakcje karuzelowe VAT” czy malwersacje podatkiem akcyzowym. Kwoty pozyskane $\mathrm{z}$ tego tytułu oscylują $\mathrm{w}$ granicach kilkudziesięciu milionów złotych na jedną grupę przestępczą [www4, dostęp: 14.03.2019]. Wielkość skali problemu przedstawiają dane $\mathrm{z}$ tabeli 2 . 
Tabela 2. Udział luki VAT w latach 2008-2013

\begin{tabular}{|l|c|c|c|c|c|c|c|}
\hline \multirow{2}{*}{$\begin{array}{l}\text { Podatek od towarów } \\
\text { i usług }\end{array}$} & 2008 & 2009 & 2010 & 2011 & 2012 & 2013 \\
\cline { 2 - 7 } & \multicolumn{7}{|c|}{ W tys. złotych } \\
\hline VAT „teoretyczny” & 121576 & 125852 & 136153 & 154832 & 158817 & 161767 \\
\hline VAT faktyczny & 102822 & 100568 & 110946 & 124820 & 118740 & 118961 \\
\hline Luka w VAT & 18754 & 25284 & 25207 & 30012 & 40077 & 42806 \\
\hline $\begin{array}{l}\text { Udział luki w VAT } \\
\text {,teoretycznym” }\end{array}$ & $15,4 \%$ & $20,1 \%$ & $18,5 \%$ & $19,4 \%$ & $25,2 \%$ & $26,5 \%$ \\
\hline
\end{tabular}

Źródło: Tratkiewicz [2016, materiały niepublikowane].

Powyższe dane wskazują na tendencję wzrostową opisywanego zjawiska. Warto wspomnieć, że proces ten napędza się niczym „karuzela”, przez co jest procesem uciążliwym w zatrzymaniu. Przy wykorzystaniu odpowiednich mechanizmów uściślających z biegiem lat uda się powstrzymać i zminimalizować proceder nielegalnego sprzeniewierzania środków publicznych.

\section{PRZECIWDZIALANIE UNIKANIU I UCHYLANIU SIĘ OD OBOWIAZZKÓW PODATKOWYCH}

Zarówno unikanie jak i uchylanie się od opodatkowania spotyka się z krytyką społeczną. W celu rozwiązania problemu administracja poszukuje metod przeciwdziałania tymże procederom. Jednym $\mathrm{z}$ działań podjętych $\mathrm{w}$ ciągu ostatnich lat jest uszczelnienie systemu podatkowego w zakresie tak zwanych „split payments", co w thumaczeniu oznacza płatność podzieloną. Jest to jeden ze sztandarowych sposobów walki $\mathrm{z}$ wyłudzeniami podatkowymi. W tym celu każdy przedsiębiorca posiada odpowiednie subkonto VAT, do którego wpływają środki pochodzące $\mathrm{z}$ transakcji sprzedaży dóbr bądź usług. Od 1 lipca 2018 roku jest możliwość rozliczania się za pomocą split payment, jednak z raportu EY dotyczącego tychże transakcji wynika, że korzystający są sceptycznie nastawieni do tego typu rozwiązań. Badanie to opublikowano na miesiąc po oficjalnym wprowadzeniu możliwości prowadzenia podzielonych transakcji. Ponad $2 / 3$ respondentów biorąca udział w badaniu wypowiada się na jego temat raczej negatywnie, nie widząc szans na uszczelnienie systemu podatkowego [Split payment..., 2018: 5]. Podatnicy nie czują się do końca przygotowani, aby wdrożyć ten rodzaj płatności. Co więcej, są świadomi korzyści wynikających z niego - jednak nie oczekują zwrotu nadwyżki podatku VAT z tego tytułu [Split payment..., 2018: 9]. Rząd przewiduje, że wykorzystanie wcześniej wspomnianego mecha- 
nizmu spowoduje wzrost gospodarczy oraz przyczyni się do odzyskania blisko 4 mld złotych [www1, dostęp: 13.03.2019].

Rozdzielona płatność nie jest jednak jedynym pomysłem uszczelnienia wielomiliardowej luki w polskim systemie podatkowym. Rok 2017 okazał się rokiem zmian w zakresie gospodarczym kraju. Doszukuje się odzyskania kwoty z tytułu podatku od towarów i usług również poprzez regulacje aparatu administracyjnego. Od 1 stycznia 2017 roku przywrócona została tak zwana sankcja administracyjna [www2, dostęp: 15.03.2019]. Definiuje się ją jako konsekwencje naruszenia przepisów prawnych, dyktowaną przez powszechnie obowiązujące przepisy podatkowe [Kruk 2013: 172].

Rok 2017 przyniósł także zmiany w zakresie podatków dochodowych. Stawka podatku dochodowego od osób prawnych dla małych przedsiębiorców została zmniejszona z $19 \%$ do $15 \%$. Zmniejszenie stawki podatkowej ma za zadanie zachęcanie podatnika do terminowego przestrzegania zobowiązań podatkowych zgodnie z prawem. Wywołującą komentarze okazała się zmiana kwoty limitu transakcji gotówkowej. W 2004 roku Ustawodawca ustanowił maksymalny limit transakcji gotówkowych dla przedsiębiorców. Wynosił on 15000 euro. Oznacza to że po przekroczeniu tej bariery przedsiębiorca ma obowiązek dokonywania transakcji tylko i wyłącznie za pośrednictwem rachunku bankowego [Ustawa z dnia 2 kwietnia 2004 r. o swobodzie działalności gospodarczej, Dz.U. 2004, nr 173, poz. 1807]. Taki stan rzeczy miał się do 13 kwietnia 2016 roku kiedy to została wprowadzona nowelizacja zmniejszająca tę kwotę do zaledwie 15000 złotych [Ustawa z dnia 13 kwietnia 2016 r. o swobodzie działalności gospodarczej, Dz.U. 2016, poz. 780]. W praktyce Urząd Skarbowy ma możliwość wglądu na rachunki bankowe, przez co ich transakcje będą jawne.

Jedną z najistotniejszych zmian jest ponowne wprowadzenie klauzuli o unikaniu opodatkowania. Wcześniej wykorzystywana w polskim systemie podatkowym została zniesiona w 2004 na skutek opinii Trybunału Konstytucyjnego. Według organu nie spełniała ona norm prawnych. Po latach zaczęła ona jednak obowiązywać ponownie i definiuje się ją jako zakwestionowanie ważności czynności podatkowych, mimo że te są skuteczne według litery prawa. W efekcie działań dochodzi do unikania opodatkowania, choć obowiązek podatkowy w teorii powinien na opodatkowanym ciążyć [www6, dostęp: 13.03.2019]. Ordynacja podatkowa przewiduje katalog czynności wyłączających klauzule z użycia. Jeśli korzyść podatkowa nie przekroczy stu tysięcy złotych w okresie rozliczeniowym nie stosuje się jej. Podobne działania stosuje się w stosunku do podatku od towarów i usług, gdzie wcześniej wspomniana klauzula nie obowiązuje, bądź do podmiotów zaopiniowanych jako zabezpieczone [www6, dostęp: 13.03.2019]. 


\section{PODSUMOWANIE}

Celem poniższego opracowania było określenie przyczyn i skutków legalnego, bądź nie, sposobu optymalizacji podatkowej. Są nimi nieustannie rosnąca chęć gromadzenia pieniędzy, źle przewartościowany system moralny podatników, a także wpływ otoczenia w którym się znajdują. Uważają oni, że dochody $\mathrm{z}$ prowadzenia przez nich działalności są w pełni ich zasługą, przez nie chcą udostępnić części swojego zysku administracji skarbowej. Skutkiem uchylania się od opodatkowania staje się więc rosnąca luka podatkowa, która dopiero w roku 2015 zaczęła być uszczelniania i doprowadzana do stanu równowagi. W praktyce dziura ta przyczynia się do uszczuplenia budżetu państwa, co ma bezpośredni wpływ na system działania administracji państwowej, a także jego podatników. Pieniądze te są bezpośrednio związane z inwestycjami, które na terenie Rzeczpospolitej są wręcz wymagane, by ta spełniała unijne standardy w kontekście infrastruktury, medycyny, edukacji czy ekologii.

Równie niebezpieczne stało się więc unikanie od opodatkowania. Ta choć łagodniejsza $\mathrm{w}$ swoim przebiegu oraz $\mathrm{w}$ większości przypadków legalna ma wręcz katastrofalne skutki dla finansów publicznych państwa. Przedsiębiorcy są skłonni nawet do zmiany państwa, które nakłada na nich podatek, licząc na zmniejszenie spoczywającego na nich ciężaru opodatkowania. W efekcie po raz kolejny dochodzi do zwiększenia dziury podatkowej oraz pogorszenie płynności finansowej państwa.

Podatnik staje więc przed wyborem, który powinien być zgodny z jego sumieniem. Może wybrać legalne i zalecane środki optymalizacji podatkowej, które są prawnie zagwarantowane przez państwo bądź wybrać drogę w oparciu o łamanie prawa, uchylanie się od opodatkowania. Musi jednak mierzyć się $\mathrm{z}$ konsekwencjami swoich działań.

Nie podlega więc dyskusji fakt, iż system podatkowy wymaga naprawy. Jednak najważniejszym elementem, który go scala jest mentalność jego podatników. Zmiany $\mathrm{w}$ prawie podatkowym doprowadzą do wymiernych wpływów w budżecie, jednak to praca nad zachowaniem mieszkańców Rzeczpospolitej jest wymagana do zmiany i poprawy jakości życia w Polsce. 


\section{BIBLIOGRAFIA}

Cieślukowski M., Kańduła S., Kijek I., 2012, Polski System Podatkowy, Wyd. UE w Poznaniu, Poznań

Dzwonkowski H.(red.), 2012, Prawo podatkowe, C.H. Beck, Warszawa.

Fundowicz J., 2016, Szara strefa w polskiej gospodarce w 2016 roku, Instytut Badań nad Gospodarką Rynkową, Warszawa.

Kowalewska E.(red.), Musiał M., 2016, Wpływ wiedzy i zachowań podatkowych Polaków na zarządzanie finansami gospodarstw domowych, Wydział Prawa i Administracji Uniwersytet Szczeciński, Szczecin.

Kruk E., 2013, Sankcja administracyjna, Wydawnictwo UMCS. ISBN 9788377844229, Lublin.

Tratkiewicz T. 2016, Luka w VAT - sposoby przeciwdziałania w Polsce $i$ Unii Europejskiej, Ministerstwo Finansów, Departament Podatku od Towarów i Usług, materiały niepublikowane, Zeszyty Naukowe Uniwersytetu Ekonomicznego w Katowicach Nr 294, ISSN 2083-8611, Katowice.

Smoleń P., 2017, Prawo podatkowe, C.H. Beck, ISBN 978-83-255-9209-7, Warszawa.

Split payment oczami przedsiębiorców Raport z badania, 2018, EY, Warszawa.

Ustawa z dnia 29 sierpnia 1997 roku - Ordynacja podatkowa, Dz.U. 2018, poz. 800.

Ustawa z dnia 26 lipca 1991 roku o podatku dochodowym od osób fizycznych, Dz.U. 2018, poz. 1509.

Ustawa z dnia 6 grudnia 2008 o podatku akcyzowym, Dz.U. 2018, poz. 1114.

Ustawa z dnia 2 kwietnia 2004 r. o swobodzie działalności gospodarczej, Dz.U. 2004, nr 173, poz. 1807.

Ustawa z dnia 13 kwietnia 2016 r. o swobodzie działalności gospodarczej, Dz.U. 2016, poz. 780.

[www1] https://businessinsider.com.pl/firmy/podatki/podatek-vat-a-split-payment-na-czympolega-uszczelnienie-vat/tyv063j [dostęp: 13.03.2019].

[www2] https://businessinsider.com.pl/polityka/zmiany-w-prawie-gospodarczym-w-2017roku/t08r6qp [dostęp: 13.03.2019].

[www3] http://doradcapodatkowyonline.eu/en/artykuly-lista/przyczyny-zjawisk-unikania-iuchylania-sie-od-opodatkowania [dostęp: 13.03.2019].

[www4] https://niezalezna.pl/98423-tak-dzialaly-vatowskie-mafie-w-polsce-policja-rozbilakolejna-z-nich [dostęp: 14.03.2019].

[www5] https://pl.wikipedia.org/wiki/Krzywa_Laffera\#/media/File:Krzywa_Laffera.svg [dostęp: 10.03.2019]

[www6] https://poradnikprzedsiebiorcy.pl/-klauzula-przeciwko-unikaniu-opodatkowaniadefinicja-i-zastosowanie [dostęp: 13.03.2019]. 


\title{
AVOIDING AND REPROPPING FROM TAXATION AS WAYS OF MANAGING THE CONSUMER'S TAX PORTFOLIO - ABOUT THREATS AND CONTRAINDICATIONS
}

\begin{abstract}
The consumer's primary goal is spending previously earned money. Earned income is the main way to keep him and his relatives. However, these, in their definition, fulfill many other, equally important functions - their discharged part supplies the State Treasury budget, which, through redistribution, is used for the activities important for the public. Very often this is met with disapproval and general tax reluctance. The article below will present the most important functions of the tax system, based on the system in effect in the territory of the Republic of Poland. It also includes taxpayers' reactions to the current legal and economic situation and will reveal the most basic ways to avoid and evade taxation.
\end{abstract}

Keywords: tax, tax system, tax avoidance, tax evasion, tax functions, tax purposes, fixed tax characteristics. 